\title{
Conformism și nonconformism ideologic în nuvela Ana Roșculeț de Marin Preda
}

Drd. MARCU Ovidiu Universitatea „Dunărea de Jos” din Galați

\begin{abstract}
The Romanian literature retains from Marin Preda's literary work "The Meeting between the Lands", "The Moromete Family", "The Intruder", "Life as a Prey", "The Most Beloved of Earthlings", nonconformist writings for the ideological recipe of the time they were written, for which the writer's opponents did not find vulnerable points in the furious attack placed under the sign of fortuitous revisionism. They represent the prose writer's resistance component, the undated part of his literary edifice, which provides his well-deserved place in the post-war Romanian literature.

Not in the same situation are the novels "Ana Rosculet", "The Unfolding" and "Dark Windows", conjunctural texts in which Preda abdicates from the ethical and aesthetic principles in order to resort to the easy schematism of socialist realism practiced by writers in the 1950s. The compromise is not excruciating nor does it get Marin Preda out of guilt, yet it has as justification two terminals of Preda's writing: the volume of short stories "The Meeting between the Lands" (1948) and the novel "The Moromete Family"- the first volume (1955).
\end{abstract}

Key words: ideological conformism, revisionism, socialist realism, conjunctural texts, compromise

Sintagma „scriitor compromis" atașată lui Preda a intrat în circulație după Revoluția din decembrie 1989 și a fost folosită frecvent de criticii literari Ion Negoițescu, Nicolae Manolescu, Sami Damian, George Geacăr care și-au asumat statutul se judecători morali ai prozatorului pe care l-au pus la indexul literaturii române pentru vinovății reale sau fictive. Noțiunile de nomenclaturist, colaboraționist folosite de criticii literari amintiți pentru etichetarea lui Marin Preda sunt nu doar injuste, cât mai ales incorecte atunci când în discuție se află un scriitor, întrucât terminologia aceasta nu provine din sfera literaturii și nu poate constitui un criteriu pe baza căruia să fie emise judecăți de valoare literară. Astfel de calificative provin din zona politicului, iar ele nu acoperă cu adevărat valoarea operei și a carierei lui Preda .

Literatura română reține din opera lui Marin Preda „Întâlnirea din Pământuri”, ,Moromeții”, „Intrusul”, ,Viața ca o pradă”, „Cel mai iubit dintre 
pământeni", scrieri nonconformise pentru rețetarul ideologic al timpului în care au fost scrise, pentru care contestatarii scriitorului nu au găsit puncte vulnerabile în atacul furibund așezat sub semnul revizionismului fortuit. Ele reprezintă componenta de rezistență a prozatorului, parte nedatată a edificiului său literar, care îi asigură locul meritat în literatura postbelică.

Nu în aceeași situație se află nuvelele „Ana Roșculeț”, „Desfășurarea” și „Ferestre întunecate”, texte conjuncturale în care Preda abdică de la principiile etice și estetice pentru a recurge la schematismul facil al realismului socialist practicat constant de scriitori în anii ' 50 . Compromisul nu este scuzabil și nici nu îl scoate din culpă pe Marin Preda, însă are ca justificare două borne ale scrisului predist: volumul de nuvele „Întâlnirea din Pământuri” (1948) și romanul „Moromeții”(1955), volumul I.

Nuvela „Ana Roșculeț”, apărută în volum în anul 1949 la Editura pentru Literatură și Artă este un exercițiu literar de echilibristică prin care Marin Preda încearcă printr-un mimetism facil să așeze o poveste de viață în schema prestabilită a realismului socialist pentru a se elibera de suspiciunile care planau asupra sa. Până la un anumit punct, textul nuvelei prezintă experiența conjugală traumatizantă pe care o traversează Ana Roșculeț și violențele la care este supusă de către concubinul ei, Tomiță „,bocsierul”.

Copleșită de greutăți, cu responsabilitatea creșterii unei fetițe de unsprezece ani, lipsită de perspective, Ana Roșculeț descoperă orizontul luminos al existenței sub farul călăuzitor al partidului și al colegilor săi, membri de partid de la Filatura Românească de Bumbac. Cu ajutorul acestora, Ana învață o meserie, își depășește condiția umilă, învață să scrie și să citească, se înscrie în partid și este trimisă în final să reprezinte muncitorimea la congresul intelectualilor din întreaga lume care luptă pentru pace, desfășurat în Polonia, la Wroclaw.

Conflictul nuvelei $\mathrm{cu}$ o deschidere în evantai, cu un crescendo care reliefează progresul înregistrat de protagoniști, beneficiază din partea autorului de aplicarea unor șabloane ale realismului socialist, intervenție care dăunează credibilității textului și transformă personajul într-o marionetă a destinului modelat de partid. Prin tehnica flash-back-ului autorul își ajută personajul să recupereze cu ajutorul visului revelator trecutul întunecat și să conștientizeze diferența dintre lumea veche ( chiaburii) și lumea nouă ( muncitorii): „Se visase cu zece ani în urmă, când plecase de la țară și intrase la stăpân. Intr-o zi de duminică rămăsese singură acasă. Ieșise apoi în oraș și se plimbase toată ziua. Spre seară a cunoscut un tânăr care lucra la Filatura Românescă de Bumbac. După o lună de zile, bărbatul a scos-o de la stăpân, iar după altă lună a fost angajată la Filatură. Acolo, 
după ce a măturat praful de bumbac aproape un an de zile $i$ s-a dat în primire o mașină." 151

Secvența citată ilustrează unul dintre clișeele epocii:înlăturarea exploatării omului de către om.Stăpânii la care lucra Ana Roșculeț trebuia să dobândească în ochii cititorilor imaginea exploatatorilor, a chiaburilor nemiloși care îi asupresc pe oamenii simpli. Bărbatul care o scoate din condiția umilă și care îi devine pentru scurt timp soț se identifică în ochii Anei cu ipostaza modernă a salvatorului, muncitorul în salopetă albastră, cu suflet generos și plin de compasiune și înțelegere care o extrage din întunericul unei lumi decadente și o cheamă la o viață nouă.

Schimbările din viața Anei încep să prindă contur după discuția deschisă purtată cu Pavel Vasile, președintele comitetului din fabrică, omul care ilustrează în text grija partidului față de oamenii muncii. Președintele este în text ipostaza comunistului umanizat de suferința semenului neajutorat, o variantă a modelului biblic răsturnat ce întrupează compasiunea, un alt clișeu al scrierilor impuse de realismul socialist.El ia asupra lui povara tinerei muncitoare pe care o încurajează recurgând la stereotipii de limbaj: „Tovarăşă, nam vrut să te învinuiesc, îi spuse cu alt glas. Ah, ce fire ai! Păi nu faci nimic, așa! Nu se trăiește așa! Nu vezi cum e la noi ?Singur nu ajungi nicăieri. Te lupți, te lupți mereu, și nu poți să schimbi nimic. Acum, gata, lasă! N-o să treacă prea mult timp și oameni ca ăștia... dar trebuie... în sfârșit! Bine că știm! D-aia îți spuneam: trebuia să vii aici, era chiar pe vremea când se făceau anchete pentru locuințele filaturii noastre." 152

Finalul întâlnirii este contaminat de același optimism forțat al președintelui, care exprimă, prin forma de plural, veghea permanentă a partidului față de clasa muncitoare: „Ei , tovarășă Ana, îmi pare bine că te-am cunoscut. Ai o viață familială chinuită, și rău ai făcut că te-ai lăsat prinsă până acuma, dar, vasăzică, bine că știm și o să ne gândim, așa că treci mâine să discutăm, să vedem ce este de făcut! Nu sta singură, tovarășă! Să nu-ți fie frică de de nimeni, auzi? Treci mâine!... noroc și spor la lucru !"153

Discursul lozincard al președintelui și îndemnul mobilizator adresat Anei de a se angaja cu toată ființa în întrecerea socialistă au rolul de a crea în subconștientul acesteia impresia că se află pe drumul cel bun al construirii unui viitor luminos la care este chemată să participe. Utopia lumii perfecte după modelul sovietic este întreținută în text de prezența jurnalului jurnalului

\footnotetext{
${ }^{151}$ Marin Preda, Opere, vol. I, Editura Univers enciclopedic, București, 2002, p. 599-600

152 Ibidem, p. 616

153 Ibidem, p. 617
} 
mobilizator al reușitelor obținute de clasa muncitoare și condamnarea odiosului trecut capitalism.

Jurnalul de informare despre succesele de la Uzinele Reșița reprezintă un astfel de preambul motivațional al filmului sovietic difuzat la cinematograf, primul film pe care Ana Roșculeț îl vizionează în compania fetiței ei căreia îi distribuie rolul de lector al subtitrării.Filmul propagandistic are un puternic impact emoțional asupra Anei care se identifică cu personajul feminin din film și simte dorința de ascensiune.

Preda introduce astfel în corpul nuvelei mitul proletarului preluat din literatura de masă care își depășește condiția precară și este prezentat ca exemplu, după ce învinge piedicile vechii orânduiri. Modelul învingătorului din filmul sovietic trezește în Ana Roșculeț convingerea că se poate elibera de prejudecăți și că poate urca la rândul ei pe scara socială: „Dar după un ceas, povestea de pe ecran, cu o țărancă ajunsă președinte de colhoz, apoi deputat în Sovietul Suprem, puse stăpânire pe ea atât de mult, încât, atunci când femeia fu încolțită de dușmanii noii orânduiri și căzu împușcată pe niște scări, Ana abia se stăpâni să nu țipe." 154

Evoluția ulterioară a Anei Roșculeț se produce sub impulsul substituirii de personalitate după reușita protagonistei din pelicula cinematografică. Cursurile de alfabetizare ale oamenilor muncii - un alt element de influență proletară preluat de Preda - sunt urmate de muncitoarea din Filatură cu un singur gând - înscrierea în partid, care să-i deschidă calea către noi orizonturi. Dificultatea Anei de a se exprima în scris este compensată în plan narativ de limbajul de lemn al comitetului de partid din fabrică (Pavel, Vișan, Constanța, Ierulescu) prin debitarea lozincilor despre sprijinul necondiționat al partidului și învinuirea sistemului capitalist.

Progresele înregistrate de lucrătoarea Ana Roșculet în dorința de a avea acces la cunoaștere vegheate de responsabila de la cadre sunt elogiate de fostul președinte al comitetului ajuns director. Autorul grefează în text două componente ale literaturii partinice: elogiile aduse oamenilor muncii în ședințele de partid, urmate, după caz, de critică și autocritică în același context.

Discursul directorului în plenul ședinței se constituie într-un prinos (prilej) de recunoștință adus Partidului clasei muncitoare care a creat: "noi condiții de viață" oamenilor muncii: „El vorbi despre cazul lucrătoarei Ana Roșculeț, care nu s-a mulțumit numai să-și aducă aminte cele ce uitase din cele trei clase primare învățate. Această tovarășă a mers cu pași repezi și, unde înainte se mulțumea

${ }^{154}$ Ibidem, pp. 632-633 
numai să doarmă, acum se afla pe un drum nou, care înainte îi era închis. Această tovarăşă a uimit pe învățătoarea ei prin setea cu care voia să învețe cât mai mult și cât mai repede." 155

Stereotipiile de limbaj, fala directorului filaturii, sunt preluate de Marin Preda din limbajul comunist standardizat al epocii impus de mijloacele de propagandă de partid, prin care se urmărea modelarea conștiinței oamenilor muncii și uniformizarea acțiunilor în scopul construirii socialismului măreț. Îndeplinirea sau depășirea planului de producție, însușirea educației socialiste, demascarea sabotorilor, atragerea cadrelor noi, lupta împotriva dușmanilor de clasă sunt doar câteva dintre clișeele lingvistice ale timpului pe care autorul le împrumută personajelor din nuvelă.

Citită în structura de suprafață, nuvela „Ana Roșculeț” are toate atributele cerute de literatura prolecultistă: efortul muncitorimii de a făuri o lume nouă, ascuțirea luptei de clasă, alfabetizarea maselor, grija protectoare a partidului față de oamenii muncii. În structura de adâncime însă, textul conține elemente care se situează pe o poziție antagonistă (opusă), aspecte care revelează concepția autorului despre rețeta impusă de ideologii literari.

În episodul filmului sovietic pe care îl vizionează protagonista nuvelei, Marin Preda strecoară câteva replici ale unor țărani, replici care nu sunt deloc întâmplătoare şi peste care critica literată a trecut cu uşurinţă: „Ei, Vanca, ai să plesneşti de atâta somn... Ce-aveți de gând, putrezește grâul pe câmp... Ce spui, Proșka! Maicuța noastră Rusia a ajuns pe mâinile femeilor... Din partea mea, eu unul nu am nevoie de nimic... Las' să putrezească. Să vedem cum o s-o scoateți la cap cu colhozurile voastre." 156

Dialogul țăranilor surprinde indiferența față de recolte, atitudine justificată prin desființarea proprietății private și trecerea terenurilor agricole în proprietatea gospodăriilor colective numite colhozuri. Modelul agriculturii rusești cu bunurile la comun a fost impus și în alte țări din sfera de influență a Uniunii Sovietice, iar entuziasmul din filmele de propagandă nu a găsit în cele mai multe situații corespondent în realitate. Țăranii nu au acceptat nici atunci când au fost constrânși să adere la gospodăriile agricole colective pentru că au văzut în această modalitate de practicare a agriculturii nu doar pierderea proprietății private, ci și o formă de subordonare economică față de statul centralizat.

\footnotetext{
${ }^{155}$ Ibidem, p. 661

156 Ibidem, p. 632
} 
Cunoscător al realității din spațiul rural Preda nu putea fi adeptul dispariței proprietății private care echivala cu dispariția clasei țărănești pentru care pământul și animalele însemnau siguranța familiei și lipsa grijilor materiale. În volumul al doilea al romanului „Moromeții”, Ilie Moromete face o analiză lucidă a acestui tip de agricultură „,bezmetic” de care se disociază:

"Agricultură de-asta în combinație o fi ea bună cui nu-i place să muncească, dar nu pentru mine, fiindcă eu dacă văd că porumbul se ingălbenește sau grâul crește rar, repede pun caii la ham, pun plugul la căruță, mă duc la deal și-l întorc, semăn din nou sus, semăn ce știu eu că îmi iese și nu pierd nimic, dar cu tine pierd, fiindcă până stau eu la discuție cu tine, până te conving că am dreptate, în fine, până te miști tu, a trecut vremea! (dacă te miști, dacă îți convine să vii de la locul unde te afli până la terenul cu pricina, că te costă benzină și carburant!) Că ați înființat voi ici-colo colhozuri și îndemnați lumea să facă la fel peste tot, păi da' ce crezi că eu nu m-am dus și n-am văzut? [...]Vite neîngrijite, nutreț risipit, pui de găină care în loc să mănânce ce li se dă, se învățaseră cu carne și se ciuguleau unii pe alții pe spinare, aveau spinările pline de sânge, apucă-te și bagă în oală o pasăre ca asta!"157

Acțiunea din volumul al doilea al romanului „Moromeții” se petrece în aceeași perioadă cu cea din nuvela „Ana Roșculeț”, iar dialogul țăranilor din film exprimă același dispreț față de principiile agriculturii socialiste total neproductive pe care îl manifestă Ilie Moromete după ce vizitase un colhoz. Vocea auctorială este în concordanță cu gândirea țăranului și exprimă cel mai bine viziunea „colaboraționistului” Preda față de aceste experimente eșuate.

Inserarea secvenței de film într-o nuvelă care prezintă reușitele industrializării forțate are o dublă semnificație: dispariția clasei țărănești prin mecanizarea agriculturii și distrugerea proprietății private, la care se adaugă urbanizarea țăranilor atrași pe șantiere, în fabrici și uzine și depopularea satelor. Neasimilarea acestora de către civilizația orașelor a contribuit la apariția conceptului de țăran urbanizat . Din rândul acestor dezrădăcinați s-a format clasa muncitoare în care se regăsește Ana Roșculeț, rămasă la periferia orașului și marcată de un complex de inferioritate.

Nuvela „Ana Roșculeț” anticipează prin elemente care țin de comicul de limbaj sau de situație aspecte ce vor contura comedia tristă a demagogiei comuniste, în care limbajul de lemn al lozincilor avea rolul de a camufla incapacitatatea conducătorilor de a se plia pe situațiile concrete. Una din lozincile epocii „,a lichida dușmanul de clasă” pune accentul pe verbul

${ }_{157}$ Marin Preda, Opere, vol. II, Editura Univers enciclopedic, București, 2002, pp. 375-376 
„a lichida” care este folosit în textele proletcultiste cu sensul a demasca, a o rupe cu trecutul capitalist, văzut ca ceva vrednic de condamnat.

În nuvelă Preda utilizează acest verb prin vocea personajului principal într-un mod voit comic, în stilul lui Caragiale: "- Ți-am spus mereu să nu te grăbești cu primirea schimbului și să mă aștepți și pe mine. Uită-te! Mai sunt două minute. Cum crezi că ai să înveți să lichidezi cu ruperea firelor?" 158

A lichida dușmanul de clasă, o lozincă preferată de conducătorii de partid devine în text sinonimă cu a lichida cu ruperea firelor de bumbac. Lozinca este reluată și parodiată în „Moromeții”, volumul II, prin intermediul lui Bilă, un personaj cu o exprimare emfatică (bombastică) și o teatralitate a gesturilor desprinsă din comediile lui Caragiale: „Bagă de seamă, cutare, spunea el cu blândețea aceea a lui din glas sub care zăcea însă ceva neliniștitor, nu vreau să vii la sfat și să lichidezi afacerea aia. Vino, domnule, și aranjează lucrurile, președintele e supărat, ți-o spun cu lacrimi în ochi." 159

Marin Preda atribuie în mod premeditat personajelor astfel de expresii peiorative tocmai pentru a arăta că nu crede în emisarii ideologiei comuniste, iscusiți țesători de intrigi și de scenarii. Ana Roșculeț și Bilă sunt marionetele unui sistem politic autoritar, iar atitudinea lor de comuniști este superficială și se menține la nivelul de salvare a aparențelor. Ei simt că lumea în care se mișcă trăiește mirajul demagogiei și își însușesc cu ușurință un anumit tip de discurs pentru a culege beneficiile imediate, fără să aibă convingerea în adevărul din spusele lor. Că așa stau lucrurile o dovedește cameleonismul personajelor invocate în contexte diferite.

Bilă este cel care îl agresează pe activistul Nicolae Moromete în timpul cuvântării despre necesitatea vânzării cerealelor la preț oficial, afirmând cu tărie că astăzi nu trebuie să fii comunist, ci anti-comunist. Același Bilă își face autocritica în ședința de analiză a campaniei agricole din Siliștea - Gumești și se arată contrariat de atitudinea lui Nae Marinescu pentru că i-a adus injurii lui și Uniunii Sovietice. După excluderea din partid, personajul își continuă recitalul și însoțește comisia de strângere a cotelor agricole din sat, chiar dacă oficial rolul lui se încheiase.

Ana Roșculeț, comunista care se străduiește să-și educe conștiința de clasă și învățăturile partidului pe care să le pună în practică, uită subit în timpul concediului de tot ceea ce a sădit mai bun partidul în ea și este înfățișată de către autor ca o comunistă cu o atitudine bovarică. Imaginea Anei în concediu este

${ }^{158}$ Marin Preda, Opere, vol. I, Editura Univers enciclopedic, București, 2002, p. 635

159 Marin Preda, Opere, vol. II, Editura Univers enciclopedic, București, 2002, p. 203 
contaminată de atracția vieții mondene: achiziționarea unei perechi de pantofi scumpi, lecturi sofisticate, plimbări nesfârșite pe bulevarde, vizionarea filmelor la cinematograf. Toate acestea contrastează cu imaginea sobră a muncitorului fruntaş preocupat de îndeplinirea planului de producție:

"Își făcuse o rochie frumoasă de vară și-și cumpărase o pereche de pantofi foarte scumpi. Dimineața se scula târziu, făcea curat și gătea ceva. Se îmbrăca și pleca în oraș, unde se plimba ore întregi, uitându-se prin vitrine ori urmărind să vadă dacă cucoanele au pantofi mai frumoși ca ai ei. Câteodată o dorință ascunsă o îmboldea să caute iar prin anticarii sau în librării o carte bună, să ia tramvaiul și să se întoarcă acasă unde să stea liniștită în patul ei și să citească. [...]Tot plimbându-se prin oraș, începuse să bage de seamă că are un trup frumos, mai frumos ca al cucoanelor pe care le vedea pe bulevard." 160

Nuvela „Ana Roșculeț” considerată de contestatarii lui Marin Preda prima concesie făcută de scriitor noului regim politic instaurat se dovedește a fi doar o adaptare superficială a unor scheme construite de către ideologii realismului socialist, pe care prozatorul le depășește cu ușurință printr-un exerciţiu de mimetism literar. Analizată cu atenție, „Ana Roșculeț” este o imagine eșuată a omului nou, o atragere neconvingătoare a contrastelor între gândirea rigidă a personajului îndoctrinat de învățăturile marxist-leniniste și atitudinea visătoare cu influențe bovarice.

Dincolo de clișeele pe care le utilizeză, ironia autorului rămâne prezentă în subsidiar, semn că Preda a dezavuat recomandările venite de la centru. Prin intermediul Anei Roșculeț care își depășește limitele ca un personaj de basm, Preda sugera morala basmului comunist: orice analfabet poate să ajungă conducător în dictatura proletară, după exemplul luminos pe care îl ilustrează reușita primei femei tractorist din URSS: "În URSS, o colhozoaică era ca dumneata, zise responsabila UFDR, care de un timp se uita interogativ la lucrătoare, nu s-a speriat deloc că nu învățase în școli superioare și că nu știa o boabă din ce-i ăla tractor. A invvățat și a ajuns prima tractoriță pe țară și pe urmă a fost aleasă deputat în Sovietul Suprem."161

Imaginea scriitorului Marin Preda rămâne în pofida nuvelelor amintite cea a unui scriitor care și-a păstrat verticalitatea morală într-o perioadă de aservire totală faţă de regimul comunist, perioadă marcată de trădări intelectuale și privilegii materiale. Posteritatea lui Preda reține operele

\footnotetext{
${ }^{160}$ Marin Preda, Opere, vol. I, Editura Univers enciclopedic, București, 2002, p. 665-666

161 Ibidem, p. 648
} 
fundamentale, în timp ce nuvelele „Ana Roșculeț”, „Desfășurarea” și „Ferestre întunecate" abia dacă sunt menționate ca piese de inventar. Nu înseamnă că textele menționate trebuie omise din bibliografia scriitorului, ci trebuie citite în cheia unei literaturi impuse, în care omul și scriitorul erau o jucărie la mâna destinului.

Lecturate în structura de adâncime nuvelele controversate relevă elemente prin care Marin Preda contestă deciziile aberante ale regimului comunist, - demască ipocrizia activiștilor de partid și denunță efectele unei politici distructive a clasei țărănești, toate acestea menținând aparențele acceptării dogmelor. Mitul scriitorului compromis pe care au încercat să-1 acrediteze contestatarii lui Preda invocând cele trei nuvele este fals și nu reușește să eclipseze impactul pe care l-au avut în epocă romanele ce l-au făcut un scriitor incomod pentru puterea politică de atunci .

\section{Bibliografie}

Preda, Marin, Opere, vol. I, Editura Univers enciclopedic, București, 2002

Preda, Marin, Opere, vol. II, Editura Univers enciclopedic, București, 2002

Grigor, Andrei, Marin Preda incomodul, Editura Porto- Franco, Galați, 1996

Rachieru, Adrian Dinu, Marin Preda. Omul utopic, Editura Eminescu, București, 1996

Spiridon, Monica, Omul subt vremi, Editura Cartea Românească, București, 1993 